\title{
Padrões de nupcialidade na economia cafeeira de São Paulo $(1860-1930)^{*}$
}

\author{
Oswaldo Mário Serra Truzzi ${ }^{* *}$
}

\begin{abstract}
O objetivo deste trabalho é apresentar e discutir as pautas matrimoniais vigentes em um município típico da economia cafeeira paulista, entre 1860 e 1930, tomando tal variável como indicador do vigor da identidade étnica e do grau de assimilação dos estrangeiros na sociedade local. São Carlos foi fundado em 1857 e conformou-se, a partir da penúltima década do século XIX, como um município bastante representativo da economia cafeeira que se desenvolveu no Estado. De fato, com uma mão de obra inicialmente composta por escravos negros, a partir dos anos 1880 o município passou a receber expressivas levas de imigrantes europeus - italianos, portugueses, espanhóis e outros numericamente menos significativos - para trabalhar nas plantações de café, a ponto de, em 1894, ter recebido o maior contingente de imigrantes de todo o interior paulista. A partir de uma análise dos 15.011 registros paroquiais de casamento observados no período, o trabalho discute a evolução das preferências matrimoniais desses diversos grupos que, ao lado de brasileiros brancos e negros, conformaram uma população estimada em 60 mil indivíduos em 1930. Os dados analisados indicam que a origem nacional atuou como condicionante muito significativo das opções matrimoniais efetivamente concretizadas até pelo menos final dos anos 1920. Assim, as evidências colhidas apontam que pelo menos as primeiras duas gerações de indivíduos de origem imigrante, que viveram em São Carlos até a Grande Depressão do final da década de 1920, mostraram-se bastante resistentes ao processo de assimilação, pelo menos sob o ângulo das pautas matrimoniais.
\end{abstract}

Palavras-chave: Casamentos. Imigração. Endogamia. Etnicidade. Economia cafeeira. São Paulo.

\section{Introdução}

Localizado no interior paulista, São Carlos foi fundado em 1857 e conformou-se, a partir da penúltima década do século XIX, como um município bastante representativo da economia cafeeira que se desenvolveu no Estado. Em 1884, por iniciativa das elites agrárias locais, a ferrovia já havia chegado à região, constituindo um poderoso incen-

\footnotetext{
* O presente trabalho foi desenvolvido no âmbito do projeto temático Observatório das Migrações em São Paulo - fases e faces do fenômeno migratório, financiado pela Fapesp e coordenado por Rosana Baeninger. O autor agrade a Cúria Diocesana de São Carlos e seus funcionários pelo acesso aos registros paroquiais de casamento. Agradecimentos também a Maria Silvia B. Bassanezi e aos vários comentários oferecidos por ocasião da apresentação de versões anteriores deste paper no IX Congreso de la Asociación de Demografía Histórica, em Ponta Delgada (Açores), no XVII Encontro Nacional de Estudos Populacionais, em Caxambu, e no 35th Annual Meeting of the Social Science History Association, em Chicago, todos ocorridos em 2010.

** Doutor em Ciências Sociais pela Unicamp, professor associado 3 da Universidade Federal de São Carlos - UFSCar e bolsista $\mathrm{PQ} / \mathrm{CNPq}$.
} 
tivo à ampliação de suas lavouras. Assim, dispondo de uma mão de obra inicialmente composta por escravos negros, a partir dos anos 1880 o município passou a receber um número muito expressivo de imigrantes europeus - italianos, portugueses e espanhóis, sobretudo - para trabalhar nas plantações de café, a ponto de, em 1894, ter recebido o maior contingente de imigrantes de toda a economia cafeeira paulista (TRUZZI, 2007; TRUZZI; BASSANEZI, 2009).

Este afluxo de imigrantes representou um enorme impacto sobre a composição da população local, conforme se pode observar na Tabela 1, que resume, em termos absolutos e percentuais, como os contingentes populacionais presentes no município se transformaram significativamente nas duas décadas subsequentes à abolição da escravidão.

A massiva entrada de imigrantes e, subsidiariamente, a saída de ex-escravos do município determinaram que, entre 1886 e 1907, a população aumentasse e tivesse sua composição racial alterada drasticamente. Os caboclos, pardos e pretos, que em
1886 somavam $55 \%$ dos 16.104 habitantes do município, reduziram-se para $12,5 \%$ de mulatos e pretos (as categorias empregadas pelo censo em 1907). Em contrapartida, os estrangeiros passaram de $12,7 \%$ para $39,4 \%$ da população, neste mesmo período. Também a população branca aumentou graças à chegada de brasileiros brancos, sobretudo oriundos de Minas Gerais e de Estados do Nordeste, que buscavam igualmente se beneficiar da prosperidade das lavouras da região.

Com a chegada dos imigrantes, principalmente a partir das duas últimas décadas do século XIX, abriu-se um novo panorama demográfico. ${ }^{1}$ Os imigrantes italianos predominaram entre os estrangeiros, atingindo, em 1907 , quase $30 \%$ do total da população do município. Além deles, espanhóis, portugueses, alemães, turcos (na verdade sírios e libaneses) e indivíduos de outros grupos numericamente não tão expressivos também compuseram o mosaico de estrangeiros presentes em São Carlos. A Tabela 2 mostra a composição numérica dos grupos mais expressivos, no período 1907-1934.

TABELA 1

Distribuição da população, por nacionalidade e cor Município de São Carlos - 1886-1907

\begin{tabular}{|c|c|c|c|c|c|c|c|c|c|c|c|c|c|c|}
\hline \multirow{2}{*}{ Anos } & \multicolumn{2}{|c|}{$\begin{array}{c}\text { Brasileiros } \\
\text { brancos }\end{array}$} & \multicolumn{2}{|c|}{$\begin{array}{c}\text { Estrangeiros } \\
\text { brancos }\end{array}$} & \multicolumn{2}{|c|}{ Caboclos } & \multicolumn{2}{|c|}{ Pardos } & \multicolumn{2}{|c|}{ Mulatos } & \multicolumn{2}{|c|}{ Pretos } & \multicolumn{2}{|c|}{ Total } \\
\hline & N. abs. & $\%$ & N. abs. & $\%$ & N. abs. & $\%$ & N. abs. & $\%$ & N. abs. & $\%$ & N. abs. & $\%$ & N. abs. & $\%$ \\
\hline 1886 & 5.209 & 32,3 & 2.039 & 12,7 & 2.906 & 18,0 & 1.957 & 12,2 & - & - & 3.993 & 24,8 & 16.104 & 100,0 \\
\hline 1907 & 18.568 & 48,1 & 15.258 & 39,4 & - & - & - & - & 1.001 & 2,6 & 3.815 & 9,9 & 38.642 & 100,0 \\
\hline
\end{tabular}

Fonte: São Paulo (1888); Recenseamento de 1907, São Carlos.

TABELA 2

Distribuição da população, por nacionalidade Município de São Carlos - 1907-1934

\begin{tabular}{|c|c|c|c|c|c|c|c|c|c|c|c|c|c|c|c|c|}
\hline \multirow[b]{2}{*}{ Anos } & \multicolumn{2}{|c|}{ Brasileiros } & \multicolumn{2}{|c|}{ Italianos } & \multicolumn{2}{|c|}{ Portugueses } & \multicolumn{2}{|c|}{ Espanhóis } & \multicolumn{2}{|c|}{ Alemães } & \multicolumn{2}{|c|}{ Turcos } & \multicolumn{2}{|c|}{ Outros } & \multicolumn{2}{|c|}{ Total } \\
\hline & $\begin{array}{c}\text { N. } \\
\text { abs. }\end{array}$ & $\%$ & $\begin{array}{c}\text { N. } \\
\text { abs. }\end{array}$ & $\%$ & $\begin{array}{c}\text { N. } \\
\text { abs. }\end{array}$ & $\%$ & $\begin{array}{c}\mathrm{N} . \\
\text { abs. }\end{array}$ & $\%$ & $\begin{array}{c}\text { N. } \\
\text { abs. }\end{array}$ & $\%$ & $\begin{array}{c}\mathrm{N} . \\
\text { abs. }\end{array}$ & $\%$ & $\begin{array}{c}\mathrm{N} . \\
\text { abs. }\end{array}$ & $\%$ & $\begin{array}{c}\text { N. } \\
\text { abs. }\end{array}$ & $\%$ \\
\hline 1907 & 23.375 & 60,5 & 11.339 & 29,3 & 1.631 & 4,2 & 1.670 & 4,3 & 209 & 0,5 & 114 & 0,3 & 304 & 0,8 & 38.642 & 100,0 \\
\hline 1920 & 40.894 & 75,4 & 8.235 & 15,2 & 1.948 & 3,6 & 2.141 & 3,9 & 202 & 0,4 & 212 & 0,4 & 593 & 1,1 & 54.225 & 100,0 \\
\hline 1934 & 44.724 & 86,6 & 4.185 & 8,1 & 950 & 1,8 & 1.109 & 2,1 & 119 & 0,2 & 150 & 0,3 & 383 & 0,7 & 51.620 & 100,0 \\
\hline
\end{tabular}

Fonte: Recenseamento de 1907, São Carlos, Recenseamento de 1920, Brasil e Censo de 1934, São Paulo. Nota: Os percentuais não somam exatamente $100 \%$ devido às aproximações decimais.

\footnotetext{
1 Para uma análise das transformações envolvendo a composição étnico-racial, condição domiciliar, perfil profissional e outras características relevantes da população no período, consultar Truzzi e Bassanezzi (2009).
} 
Se a distribuição por nacionalidades registrou que os brasileiros constituíam em 1907 mais de $60 \%$ da população do município e, em 1920, mais de $75 \%$, não se pode esquecer, contudo, que entre estes brasileiros encontravam-se arrolados muitos filhos de estrangeiros nascidos no Brasil, em função da norma vigente do jus soli. ${ }^{2}$ Em 1934, obviamente, tal processo só se fez agravar.

Em relação à época de chegada dos imigrantes estrangeiros, pode-se dizer que os alemães, embora pouco numerosos (somavam 371 indivíduos em 1886, número que diminuiu para 210 em 1907), foram os primeiros a chegar à região, dada a relativa proximidade com Limeira e Rio Claro, localidades pioneiras na recepção deste grupo. Logo foram seguidos pelos italianos, que conformaram o grosso das hostes até o início do século XX. A partir de então, os espanhóis constituíram o grupo numericamente mais relevante, acompanhados de perto pelos portugueses, estes também presentes desde o início do período imigratório (TRUZZI, 2008, p. 58). ${ }^{3}$

O objetivo deste texto é apresentar e discutir os padrões de nupcialidade vigentes em São Carlos entre 1860 e 1930. Ao longo desse extenso período, muitas transformações ocorreram no município, mas, de modo geral, sua trajetória pode ser tomada como a de um município típico da economia cafeeira paulista da época. O interesse é investigar o comportamento matrimonial dos diferentes grupos - especialmente de imigrantes estrangeiros - que acorreram ao município, procurando, na medida do possível, inferir como evoluíram as opções conjugais no transcorrer destas sete décadas. A partir de então, procura-se interpretar tais padrões, sobretudo em termos de suas consequências para se repensar a persistência das identidades étnicas de origem e o timing específico de incorporação plena dos imigrantes à sociedade paulista.

"A escolha do cônjuge em todas as sociedades humanas, sejam tribais, civilizadas, rurais, urbanas, tradicionais ou modernas, tem suas regras" (LEVY, 2009, p.117). Sociologicamente, o casamento encerra em si todo um conjunto de significados - estratégia de seleção de parceiros, de negociação entre famílias, de reprodução do grupo - e, no caso de imigrantes, sinaliza a disposição em permanecer na terra de destino e o vigor das identidades de origem. A esse respeito, embora nenhuma variável possa refletir completamente o processo de assimilação ou a preservação da identidade étnica de tais grupos, sem dúvida o casamento constitui uma variável-chave. ${ }^{4}$

Interpretado como um instante de condensação de percepções e afinidades entre diferentes grupos, o casamento apresenta, em relação a outros indicadores, a vantagem de ser um ato específico que pode ser medido objetivamente. "Todo casamento é [...] precedido necessariamente de ajustes e entendimentos entre os futuros cônjuges ou entre suas famílias, e ainda entre intermediários socialmente definidos" (AZEVEDO, 1986, p.4). Assim, na medida em que a percepção (internalizada) ou pressão (exercida socialmente, por exemplo, pela família) de diferenças culturais significativas entre distintas origens - regiões e países - influencia preferências matrimoniais, o casamento pode ser tomado como indicador do vigor da identidade étnica: "tratando-se de imigrantes, o seu estudo ajuda a medir o grau de assimilação ou resistência do grupo à terra hospedeira" (BASSANEZI, 1996, p. 267).

\footnotetext{
2 Termo latino que significa "direito de solo" e indica um princípio pelo qual uma nacionalidade é concedida a um indivíduo de acordo com seu lugar de nascimento. O jus soli contrapõe-se ao jus sanguinis, que determina o "direito de sangue". O jus soli foi aplicado principalmente por países que receberam grande fluxo de imigrantes, com o objetivo de criar laços permanentes entre estes novos cidadãos e o território onde viviam.

3 Os italianos também constituíam, em 1940, o grupo mais idoso entre todas as nacionalidades presentes no Estado de São Paulo, o que confirma a anterioridade de sua chegada para todo o Estado. Consultar Levy e Scarano (1999, p. 63). 4 Classicamente, a bibliografia utiliza, além das pautas matrimoniais, a análise da distribuição espacial (padrões residenciais), a sociabilidade (avaliada pela pujança das associações étnicas) e a inserção política dos diversos grupos étnicos (consultar DEVOTO, 2004).
} 
Influenciar a preferência matrimonial não significa determinar. De modo geral, Miguez et al. (1991, p. 783) argumentam existirem pelo menos quatro fatores (ainda que seja difícil isolá-los) que se articulam na seleção do cônjuge: o atrativo físico (plano instintivo); a complementaridade de personalidades (plano psicológico); a compatibilidade das pautas, valores e comportamentos culturais (plano cultural); e os fatores de pressão social externos ao indivíduo (plano social). Como esses dois últimos fatores encontram-se intimamente relacionados à identidade étnica de cada indivíduo ou grupo de indivíduos, as pautas matrimoniais fornecem certa aproximação ao grau de homogeneização étnico/racial de uma sociedade receptora de imigrantes, atuando tanto como causa quanto consequência dos processos de integração social. 5

Metodologicamente, o trabalho compila e analisa os registros paroquiais de casamento relativos ao município, de 1860 a 1930. Entre as fontes disponíveis, a Cúria Diocesana foi considerada mais apropriada do que o Cartório de Registro Civil por registrar com maior precisão a procedência dos cônjuges. Além disso, no período histórico pesquisado, os padres católicos constituíam parte da minoria letrada capaz de registrar os acontecimentos e a Igreja Católica desempenhava papel central, predominando em diversos aspectos da vida sociocultural dos habitantes da cidade, tanto de brasileiros como de estrangeiros. Em muitos casos, pode-se considerar a atuação da Igreja mais forte e constante do que a dos cartórios, sobretudo em se tratando de imigrantes de origem latino-mediterrânea.

Em tese, ${ }^{6}$ as informações constantes nos registros são: data e local de ocorrência do casamento; nomes, idades e respectivas nacionalidades dos cônjuges; nomes dos pais e padrinhos; e, muito raramente, profissões dos nubentes. Para selecionar os dados pesquisados, foi desenvolvida uma tabela com alguns desses campos. Após serem preenchidas, as tabelas foram digitalizadas num software específico para facilitar a análise dos dados coletados.

Como qualquer fonte documental, seu emprego tem vantagens e limitações. Entre as primeiras, a principal é o registro sistemático das informações acima arroladas, ao longo de um extenso período.

Entre as principais desvantagens do uso de tal fonte, a mais grave diz respeito à ausência de informações quanto à cor dos nubentes (embora se mencione a condição de escravos anteriormente a 1888), o que seria particularmente interessante do ponto de vista de uma análise racial das preferências matrimoniais. Outras deficiências, embora menos importantes, devem ser mencionadas: a não distinção entre habitantes urbanos e rurais (a partir do que seria possível testar a hipótese da influência do local de moradia sobre as opções conjugais, em particular a de uma menor endogamia para os primeiros, sujeitos a um mercado matrimonial mais diversificado); $;^{7}$ o fato de os registros não captarem as chamadas uniões consensuais, ao que tudo indica numericamente mais relevantes nos anos anteriores à imigração em massa, isto é, quando o

\footnotetext{
${ }^{5}$ Além da ampla bibliografia disponível sobre o tema referenciada ao final do texto, consultar: a obra clássica de Barron (1946) e Sollors (2000), para uma perspectiva inter-racial; Goebel (2009), para o caso uruguaio; Mittelbach e Moore (1968), para o caso de americanos de origem mexicana; Otero (1990), para o caso de franceses na Argentina; Moya (1998), para o caso de espanhóis em Buenos Aires; Pagano e Oporto (1988), para o caso de italianos no bairro de La Boca em Buenos Aires; e a coletânea organizada por Breger e Hill (1998).

6 Há poucas variações entre as informações registradas, a principal delas refere-se ao grau de detalhamento do local de nascimento dos cônjuges.

7 Sabe-se, entretanto, que em 1907 a população com domicílio rural respondia por $78 \%$ do total do município (TRUZZl; BASSANEZI, 2009), percentual que em 1934, após a grande crise cafeeira e o decorrente êxodo rural, declinou para $60 \%$ (Censo de 1934).
} 
percentual de estrangeiros na população era menor; ${ }^{8}$ e a ausência de informações sobre casamentos de não católicos, avaliada como pouco significativa em virtude dos grupos que constituíram a população local.

\section{Universo analisado e aferição da endogamia}

No período estudado, foram registrados 15.011 casamentos em São Carlos, envolvendo 30.022 cônjuges. Deste total, $95,3 \%$ (28.603) tiveram suas respectivas nacionalidades identificadas. Um panorama da evolução do número de casamentos católicos registrados no período pode ser observado no Gráfico 1. A linha superior totaliza o número de casamentos de escravos (até 1888) e de livres, ocorridos na Igreja Matriz de São Carlos e nas paróquias de Ibaté (a partir de 1906) e Santa Eudóxia (a partir de 1910), distritos afastados do núcleo urbano principal do município.

Entre os aspectos mais significativos, podem-se notar, claramente: a crescente ocorrência de casamentos ao longo das três

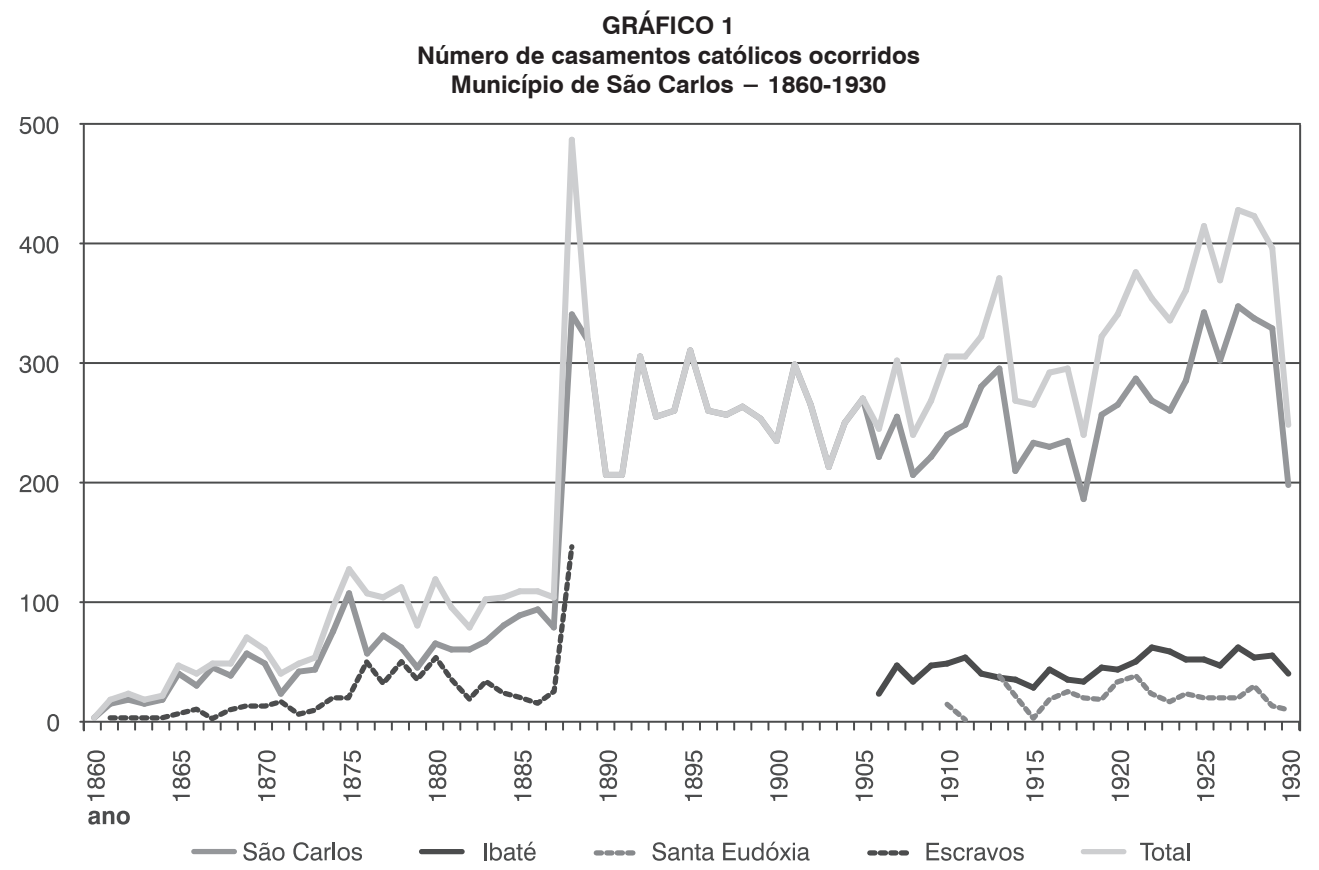

Fonte: Livros Paroquiais de Registro de Casamentos, 1860-1930.

\footnotetext{
8 Um indicador aproximado das uniões consensuais constitui a taxa de ilegitimidade (porcentagem de filhos ilegítimos entre nascidos vivos), cujos valores em 1886, 1907 e 1920 eram, respectivamente, de 17,2\%, 2,2\% e 1,1\%. Por outro lado, as taxas de nupcialidade calculadas para estes anos foram de $6,8,7,6$ e 6,8 casamentos por mil habitantes, respectivamente. Conclui-se então que a taxa de nupcialidade pode ter sofrido variações, mas a longo prazo não se alterou, mesmo que a população total tenha aumentado muito (de 16.104 indivíduos, em 1886, para 54.225, em 1920), enquanto a taxa de ilegitimidade caiu abruptamente com a chegada dos imigrantes. Tomando esta como indicador aproximado das uniões consensuais, pode-se portanto afirmar que estas eram mais importantes nos anos iniciais do período analisado (próximo a 1883) do que mais tarde, pois, com a chegada massiva dos imigrantes e a crescente participação relativa destes na população total, estas tenderam a diminuir ao longo do tempo. Mais difícil, entretanto, é avaliar o impacto da não consideração das uniões consensuais nos resultados acerca de assimilação via casamento. Em tese, a presença de brasileiros(as) no casamento, como foi visto, favorece a possibilidade de uniões consensuais, o que nos levaria a afirmar que a não consideração das uniões consensuais tende a subestimar as taxas de endogamia entre brasileiros(as). Mas esta presença pode ocorrer também quando estes (sobretudo as brasileiras) se casam com estrangeiros (exogamia), interessados em deixar em aberto a possibilidade de retorno à terra natal (TRUZZI; BASSANEZI, 2009; BASSANEZI, 2000; BASSANEZI; FRANCISCO, 2004).
} 
primeiras décadas; o pico abrupto de casamentos ocorridos por ocasião da abolição da escravatura e sua posterior estabilização em um patamar nitidamente superior ao período anterior; a diminuição relativa dos casamentos durante a Primeira Guerra Mundial; e a retomada de crescimento do número de casamentos até a brusca diminuição observada em 1930, ano de crise.

Em que medida membros de determinada origem casaram-se entre si e como este padrão se modificou com o tempo? Existem, na literatura, vários indicadores de endogamia matrimonial9 (ou exogamia), dos quais os de uso mais comum são o percentual de endogamia segundo o sexo e o índice de endogamia, este calculado para todo o grupo independentemente do sexo. Por haver vantagens e desvantagens na utilização de cada um desses indicadores, seu uso complementar é oportuno. Para ilustrar a diferença entre os indicadores, é interessante comparar duas situações hipotéticas, resumidas na Tabela 3.

Observe-se que o cálculo do percentual de endogamia masculina produz o mesmo resultado $(50 \%)$ para as duas situações, embora estas sejam bastante diferentes. De fato, na primeira, os homens de origem A se casam com todas as oito mulheres disponíveis de mesma origem; enquanto na segunda situação há muito mais mulheres disponíveis (80), embora os mesmos 16 homens só se casem com oito delas. Isso quer dizer que a razão de sexo entre os cônjuges disponíveis de uma mesma origem não influencia o indicador (no caso o percentual de endogamia masculina). Assim, embora seu cálculo seja bastante simples, os percentuais de endogamia não levam em consideração as - digamos assim - "condições de oferta" do mercado matrimonial, o que obviamente influencia as possibilidades de endogamia.

O índice de endogamia, por sua vez, busca solucionar tal problema ao levar em conta o total do contingente, sendo por isso calculado para determinada origem, e não por origem e sexo. Ele traduz a relação entre o número de matrimônios endogâmicos efetivamente ocorridos e o número esperado caso os casamentos ocorressem ao azar (isto é, sem a influência da origem). Se estes dois números são semelhantes, o índice se aproxima de zero; se a endogamia for total, o índice assume o valor 1 ; e, ao contrário, se só existirem uniões exogâmicas, o índice passa a valer $-1 .{ }^{10}$ Nos exemplos propostos, os índices calculados são de 0,32 (padrão endogâmico), para a primeira situação, e de -0,40 (padrão exogâmico), para a segunda.

TABELA 3

Cálculo do percentual de endogamia: duas situações diferentes

\begin{tabular}{|c|c|c|c|c|c|c|c|c|c|}
\hline \multicolumn{5}{|c|}{ Situação 1} & \multicolumn{5}{|c|}{ Situação 2} \\
\hline \multirow[b]{2}{*}{ Mulheres } & \multicolumn{4}{|c|}{ Homens } & \multirow[b]{2}{*}{ Mulheres } & \multicolumn{4}{|c|}{ Homens } \\
\hline & Origem A & $\begin{array}{l}\text { Outras } \\
\text { origens }\end{array}$ & $\begin{array}{l}\text { Total de } \\
\text { homens }\end{array}$ & $\begin{array}{l}\text { Endogamia } \\
\text { homens }\end{array}$ & & Origem A & $\begin{array}{c}\text { Outras } \\
\text { origens }\end{array}$ & $\begin{array}{l}\text { Total de } \\
\text { homens }\end{array}$ & $\begin{array}{c}\text { Endogamia } \\
\text { homens }\end{array}$ \\
\hline Origem A & 8 & 8 & 16 & $50 \%$ & Origem A & 8 & 8 & 16 & $50 \%$ \\
\hline $\begin{array}{l}\text { Outras } \\
\text { origens }\end{array}$ & 0 & 2 & 2 & & $\begin{array}{l}\text { Outras } \\
\text { origens }\end{array}$ & 72 & 8 & 80 & \\
\hline $\begin{array}{l}\text { Total de } \\
\text { mulheres }\end{array}$ & 8 & 10 & 18 & & $\begin{array}{l}\text { Total } \\
\text { mulheres }\end{array}$ & 80 & 16 & 96 & \\
\hline $\begin{array}{l}\text { Endogamia } \\
\text { mulheres }\end{array}$ & $100 \%$ & & & & $\begin{array}{l}\text { Endogamia } \\
\text { mulheres }\end{array}$ & $10 \%$ & & & \\
\hline
\end{tabular}

Fonte: Elaboração do autor.

\footnotetext{
9 Daqui para frente referida apenas como endogamia (ou exogamia). Para uma discussão das diferentes acepções dos termos endogamia / homogamia (e seus opostos), consultar o número especial da revista Ethnics (1975).

10 No Anexo, é explicado o modo como se calcula o índice de endogamia.
} 


\section{Os resultados obtidos}

Para analisar a evolução dos padrões de casamento observados, é interessante, em primeiro lugar, atentar para o período de 1860 a $1887 .{ }^{11}$ Ocorreram, entre esses anos, 1.996 casamentos envolvendo 3.992 cônjuges, dos quais 3.902 tiveram suas nacionalidades identificadas. Destes, 2.553 eram brasileiros livres, 1.072 eram escravos e 277 estrangeiros.

Como a variável cor não consta dos registros, é possível observar apenas que a condição de escravo ou livre define os padrões de casamento no período. De fato, em 1861 ocorreram os primeiros três casamentos de escravos, que somaram 542 em todo o município, até 1887. A enorme maioria desses casamentos envolvia cônjuges na mesma condição de escravos, embora existam 12 exceções: nesses casos, era mais comum escravo se casar com brasileira livre (um em 1874, dois em 1878, um em 1882, três em 1884 e quatro em 1887) do que brasileiro livre se casar com escrava (apenas um caso em 1883).
Do exposto conclui-se que houve uma forte endogamia quanto à condição de escravos ou livres, o que não constitui um resultado surpreendente.

Outros resultados derivam da análise dos padrões matrimoniais entre nacionalidades e, para tanto, serão considerados os casamentos das nacionalidades predominantes (brasileiros livres, italianos, ${ }^{12}$ portugueses e espanhóis), no período de 1883 a 1930. Tanto em 1886, quanto em 1907 e 1920, tais nacionalidades somavam cerca de $98 \%$ da população do município (Tabelas 1 e 2).

No tocante ao percentual de endogamia masculina, os resultados obtidos encontramse expostos no Gráfico 3, construído a partir dos dados da Tabela 1 do Anexo.

Para os grupos imigrantes, os anos iniciais oscilam bastante em razão de o número de casamentos ainda ser pequeno (no caso de espanhóis não há). A falta de mulheres no período inicial inibe um percentual maior de endogamia, tendência que se firmou a partir dos anos de maior volume migratório para cada etnia: no caso de italia-

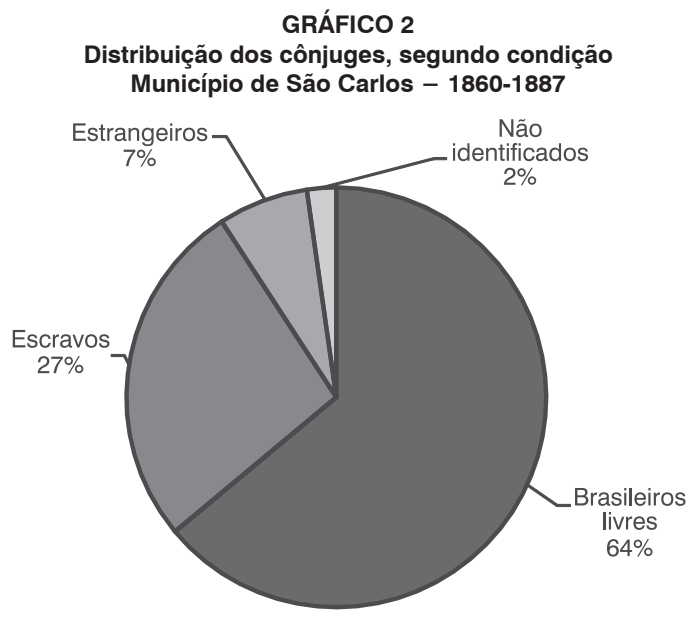

Fonte: Livros Paroquiais de Registro de Casamentos, 1860-1930.

\footnotetext{
11 Os livros paroquiais de registro de casamento adotam a expressão "ex-escravo" entre março e outubro de 1888. A partir de então, todos são simplesmente mencionados como brasileiros.

12 Nesse grupo foram incluídos os austríacos, pois algumas áreas de emigração, como o Trentino, Tirol Meridional, Trieste e Ístria, permaneceram sob domínio austríaco até o final da Primeira Guerra Mundial, quando partes dessas regiões foram incorporadas à Itália.
} 
GRÁFICO 3

Percentuais de endogamia masculina, por nacionalidade Município de São Carlos - 1883-1930

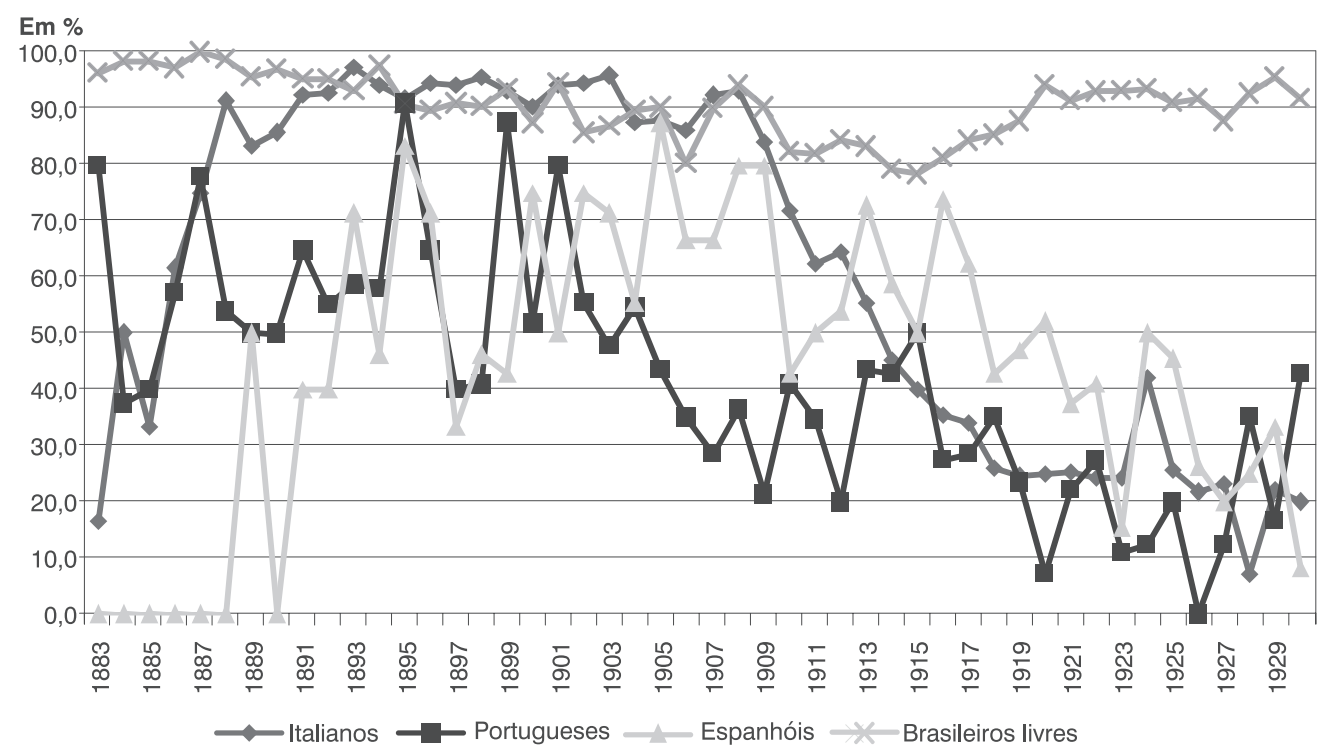

Fonte: Livros Paroquiais de Registro de Casamentos, 1883-1930.

nos, a partir da abolição; no de portugueses e espanhóis, a partir da virada do século.

Para os italianos, nota-se que, entre 1888 e 1909, o percentual de endogamia masculina nunca é inferior a $80 \%$ - a média do período é de $91,5 \%$-, o que significa dizer que, para cada 100 italianos, 91 se casavam com italianas no período. Trata-se, portanto, de uma endogamia masculina bastante expressiva. A partir de 1910, o percentual declina de modo consistente, chegando a apenas 20\% em 1930 (1924 e 1928 são pontos fora da curva). Tal queda abre caminho para duas hipóteses. A princípio, poderíamos interpretar tais dados como indicadores de que os italianos, a partir de 1910, estariam de fato se misturando de forma crescente. Entretanto, outra hipótese mais consistente é que, a partir da segunda década do século XX, os italianos passaram a crescentemente dispor de filhas de italianos nascidas no Brasil (portanto brasileiras) com idade para se casar. Nesse caso, observa-se o que alguns autores (MíGUEZ et al., 1991, p. 802; DEVOTO, 2004, p. 327; BORGES, 2009, p. 269) denominam de endogamia oculta, ou seja, um padrão nupcial ainda endogâmico do ponto de vista étnico-cultural, mas não endogâmico de um ponto de vista formal, em decorrência da legislação brasileira do jus solis. Logo adiante este ponto será novamente abordado.

Tudo o que foi dito aqui para italianos aplica-se igualmente a espanhóis, com algumas especificidades. A curva dos espanhóis oscila mais do que a dos italianos em virtude do menor número de indivíduos presentes, mas sua configuração é semelhante, com exceção do fato de que ela se apresenta mais deslocada para a direita, em função da chegada mais tardia dos espanhóis em relação aos italianos. Já no caso de portugueses, uma razão de sexo extremamente desequilibrada (Tabela 4) impõe uma taxa de endogamia masculina menor ao longo de todo o período analisado. Ela é semelhante à dos italianos apenas nos períodos iniciais, para depois se assemelhar à dos espanhóis (no que concerne à oscilação), também em virtude do menor número de indivíduos observados. 
As maiores taxas exogâmicas de portugueses provavelmente também foram favorecidas pela precoce urbanização do grupo em relação a outros estrangeiros (nesse ponto, em nítido contraste com os espanhóis, mais rurais), conforme indica a Tabela 5. Em tese, o meio urbano favorecia os casamentos exogâmicos por aumentar as opções disponíveis, enquanto nas fazendas cafeeiras, em que pese a mobilidade geográfica das famílias de colonos em busca de melhores condições de trabalho, o mercado matrimonial se apresentava mais circunscrito aos limites da própria fazenda ou da vizinhança, no interior dos quais os contatos eram mais frequentes (BASSANEZI, 1996, p. 274).

Por fim, observam-se os percentuais persistentemente elevados de endogamia masculina para brasileiros, ao longo de todo o período. Tal resultado espelha as dificuldades que os homens brasileiros enfrentavam para se casar com mulheres imigrantes em um contexto no qual estas eram bastante disputadas pelos homens de mesma nacionalidade, devido à sua escassez relativa. ${ }^{13}$ De fato, entre estrangeiros, uma razão de sexo de 1,20 significa que $17 \%$ dos homens não encontravam mulheres de mesma origem disponíveis para se casar.
O mesmo tipo de análise pode ser realizado para os percentuais de endogamia feminina por nacionalidade, apresentados no Gráfico 4 e na Tabela 2 do Anexo. De imediato, pode-se notar que as curvas para mulheres estrangeiras partem de valores mais elevados (em relação aos percentuais para homens estrangeiros, expostos no Gráfico 3 e na Tabela 1 do Anexo). Em contrapartida, os percentuais de endogamia para brasileiras são menores do que para os homens brasileiros. Em um contexto de relativa escassez de mulheres estrangeiras, ambos os movimentos refletem a já aludida "reserva" destas para homens estrangeiros e, ao mesmo tempo, a maior predisposição desses homens imigrantes (em relação às mulheres imigrantes) em se casar com brasileiras. Recordem-se aqui os famosos versos de Alcântara Machado (1927): "Carcamano pé de chumbo / calcanhar de frigideira / quem te deu a confiança / de casar com brasileira?"

As italianas, a exemplo dos italianos, apresentam taxas de endogamia superiores às de espanholas e portuguesas, estas últimas situadas agora a meio termo entre as duas primeiras. Também a partir de 1910, os percentuais diminuem para todas as mulheres estrangeiras (embora em ritmo

TABELA 4

Razões de sexo, por nacionalidades

Município de São Carlos - 1907-1920

\begin{tabular}{ccccccc}
\hline Anos & Italianos & Portugueses & Espanhóis & Estrangeiros & Brasileiros & Total população \\
\hline 1907 & 1,19 & 1,54 & 1,09 & 1,21 & 1,02 & 1,09 \\
1920 & 1,13 & 1,54 & 1,24 & 1,20 & 1,04 & 1,07 \\
\hline
\end{tabular}

Fonte: Recenseamento de 1907, São Carlos e Recenseamento de 1920, Brasil.

TABELA 5

Taxas de urbanização, por nacionalidades Município de São Carlos - 1907-1934

Em porcentagem

\begin{tabular}{ccccccc}
\hline Anos & Italianos & Portugueses & Espanhóis & Estrangeiros & Brasileiros & Total população \\
\hline 1907 & 15,8 & 23,7 & 12,7 & 17,0 & 25,5 & 22,2 \\
1934 & 46,2 & 51,5 & 39,9 & 46,9 & 39,3 & 40,3 \\
\hline
\end{tabular}

Fonte: Recenseamento de 1907, São Carlos e Censo de 1934, São Paulo.

\footnotetext{
13 Para uma confirmação do fenômeno em outro município (Rio Claro), consultar Bassanezi (1996, p.270 e seguintes).
} 
menor do que para os homens), em padrão semelhante ao já analisado anteriormente. No tocante às brasileiras, os percentuais de endogamia decrescem a um ritmo mais agudo do que para os brasileiros até a Primeira Guerra Mundial, mas, a partir daí, se elevam, refletindo provavelmente a interrupção da chegada de novos imigrantes e a menor capacidade do município de atrair novos contingentes a partir dos anos 1920.

Finalmente, para complementar a análise, observe-se no Gráfico 5 e na Tabela 3 do Anexo como evoluíram os índices de endogamia para cada nacionalidade, estes - recorde-se - variando entre 1 (endogamia total), 0 (em que não há influência da nacionalidade) e -1 (exogamia total).

A constatação mais evidente é que, durante os 48 anos observados, a nacionalidade exerceu influência considerável sobre a opção conjugal de todas as nacionalidades analisadas. De fato, com exceção de um único ponto (o ano de 1927 para os de nacionalidade brasileira), em todos os outros anos e para quaisquer grupos, o índice foi positivo, o que significa dizer que o casamento entre conacionais tendeu a ocorrer com maior frequência do que seria esperado, tendo em vista as características numéricas da oferta de nubentes.

Excetuando-se o período inicial, de maior dispersão, a partir da abolição, as curvas de italianos e brasileiros são bastante similares ao longo do restante do período analisado. Elas indicam uma endogamia bastante alta (índices maiores ou próximos a 0,80 ) entre a abolição e 1909, uma expressiva queda a partir de então até o final da Primeira Guerra Mundial (quando os índices se situam próximos a 0,20) e uma relativa estabilização até o final do período (entre 0,20 e 0,30 ). Tais perfis parecem confirmar a hipótese de que, a partir de 1909, e de maneira crescente, assistimos a um incremento de casamentos entre italianos(as) e brasileiros(as) filhos(as) de italianos(as), configurando o fenômeno da endogamia oculta. Esta tendência ocorre até determinado ponto, a partir do qual o índice tende a se estabilizar.

GRÁFICO 4

Percentuais de endogamia feminina, por nacionalidade Município de São Carlos -1883-1930

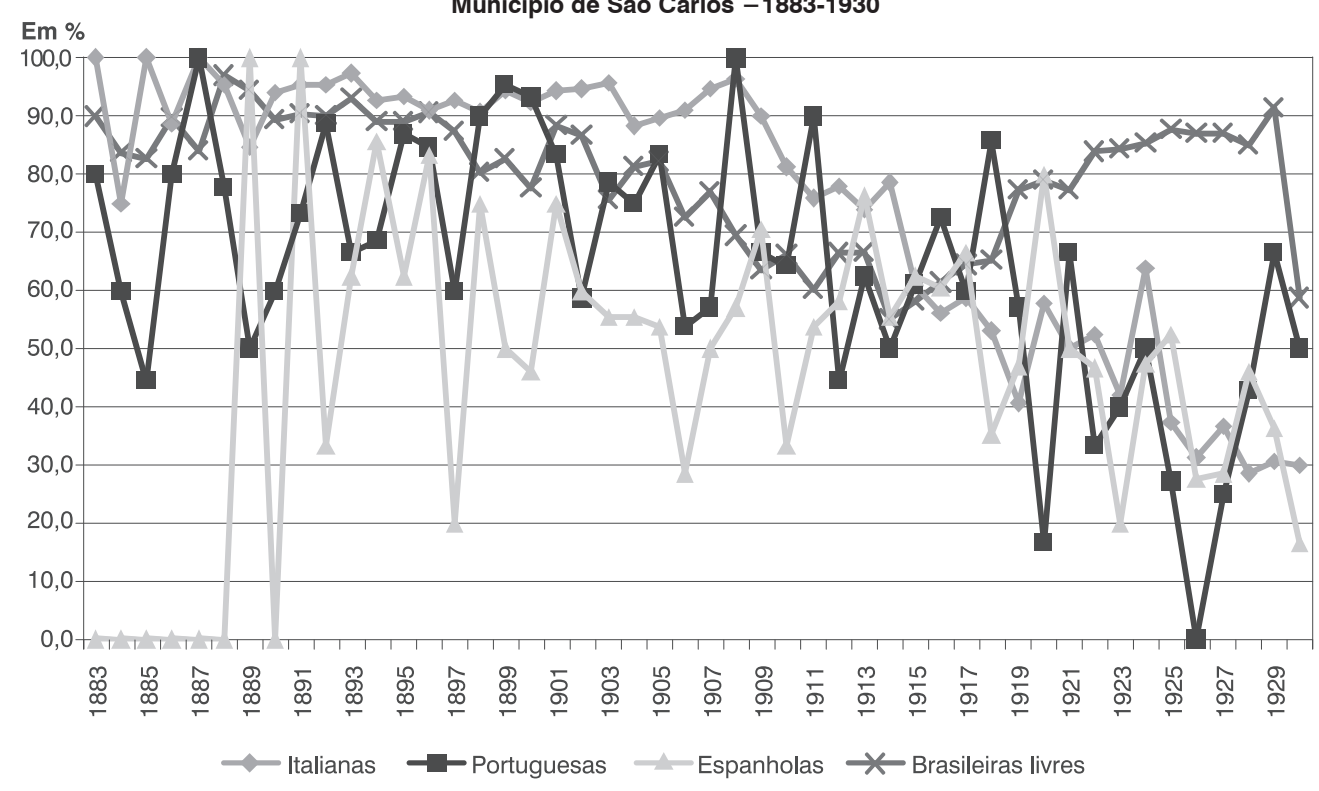

Fonte: Livros Paroquiais de Registro de Casamentos, 1883-1930. 


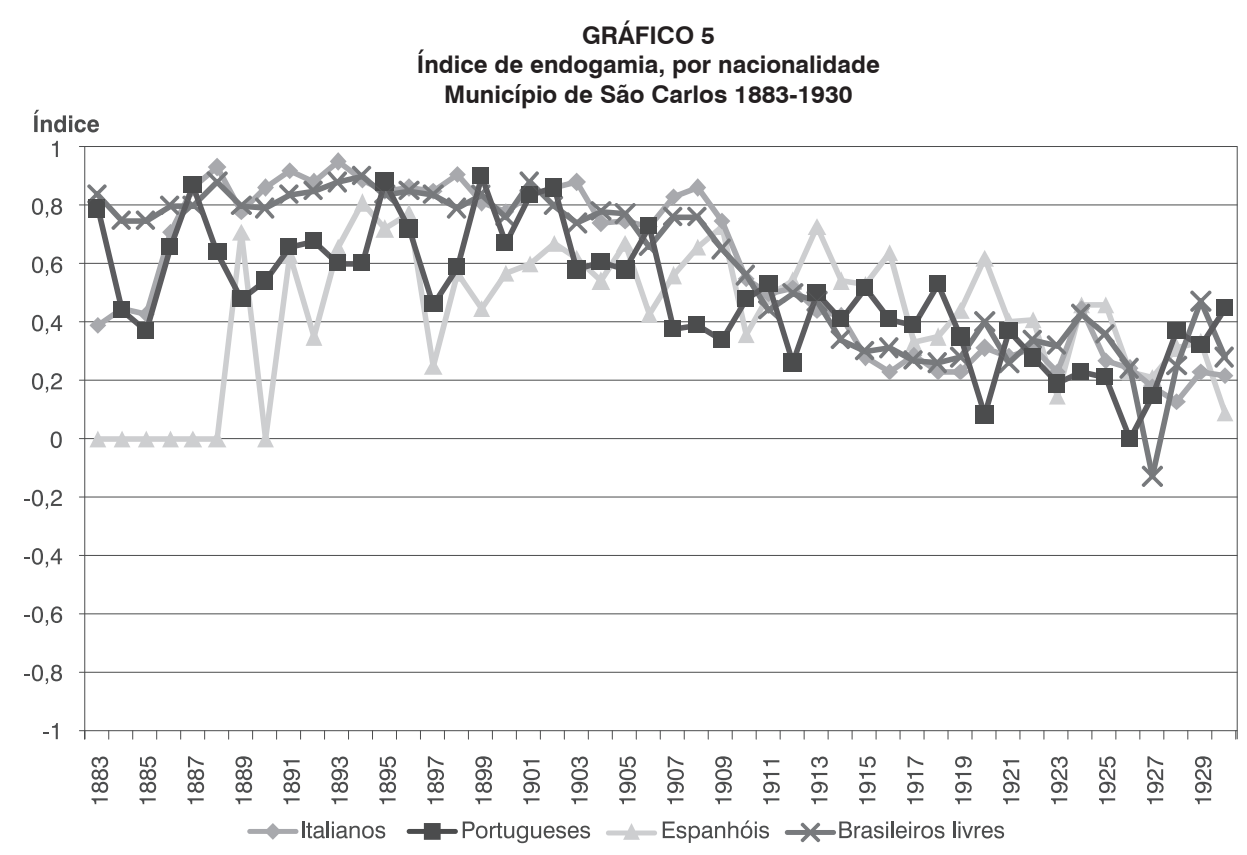

Fonte: Livros Paroquiais de Registro de Casamentos, 1883-1930.

Para os portugueses e espanhóis, os índices tendem a se situar em níveis menores do que os de italianos e brasileiros, revelando uma menor tendência endogâmica. Apenas no período correspondente à Primeira Guerra Mundial, os índices endogâmicos de portugueses e espanhóis tendem a ser mais elevados do que os de italianos e brasileiros, talvez porque os oriundi tenham, com a entrada da Itália no conflito em 1915, abandonado antes suas expectativas de retorno e resolvido se estabelecer definitivamente no Brasil. ${ }^{14}$

\section{Italianos: endogamia oculta}

Os percentuais de endogamia masculina e feminina até aqui apresentados, bem como o índice de endogamia, não levam em conta o fenômeno da endogamia oculta, conforme mencionado anteriormente. ${ }^{15} \mathrm{Ela}$ ocorre quando o cônjuge, embora nascido no Brasil, apresenta o pai ou a mãe (ou ambos) nascidos na origem enfocada (o cálculo da endogamia oculta para italianos ${ }^{16}$ deve computar as categorias expressas na Tabela 6). Procurou-se investigar sua rele-

\footnotetext{
14 Entre espanhóis, fenômeno semelhante parece ter ocorrido a partir de 1936 com a eclosão da guerra civil. Também é preciso lembrar que, a partir da segunda década do século XX, os italianos passaram a ter a opção de se casar com filhos(as) da própria colônia (endogamia oculta). Como portugueses e espanhóis configuraram uma imigração mais tardia, estes grupos só irão experimentar tal fenômeno mais tarde, o que contribuiu para incrementar seus índices de endogamia relativamente aos italianos. Os índices endogâmicos mais elevados de portugueses e espanhóis duraram mais ou menos dez anos, o que coincide com o período aproximado de anterioridade da imigração italiana em relação à portuguesa e espanhola.

${ }^{15}$ A não compilação da endogamia oculta induz a avaliações equivocadas, como a de Franco Cenni, que atribui aos italianos uma maior capacidade de fusão graças à maior proporção de casamentos destes com brasileiras (CENNI, 2002, p. 294-5). Ora, tendo o fluxo migratório de italianos precedido em boa medida o grosso da imigração portuguesa e espanhola, boa parte dessas brasileiras constituía-se, na verdade, de filhas de italianos.

16 Para uma estimativa da endogamia oculta, elegeram-se apenas os italianos, tanto por formarem o maior contingente de imigrantes, quanto pelo fato de seus sobrenomes serem mais facilmente identificáveis (em relação aos brasileiros) do que os de portugueses e espanhóis.
} 
vância, embora os registros de casamento somente apontem as nacionalidades dos cônjuges, e não as de seus pais. Mesmo assim, elegeram-se os anos de 1900, 17 1905, 1910, 1915, 1920 e 1925 para se realizar um exame mais minucioso dos sobrenomes dos nubentes, cujos resultados são expressos na Tabela 6. Ao se refazerem os cálculos dos percentuais de endogamia masculina e feminina, bem como o índice de endoga- mia, para tais anos, considerando-se agora a endogamia oculta, chega-se aos perfis delineados nos Gráficos 6 e 7, a partir dos dados das Tabelas 4 e 5 do Anexo.

O Gráfico 6 mostra que, corrigindo-se os percentuais de endogamia masculina e feminina de modo a incluir a endogamia oculta, mais de $80 \%$ dos cônjuges italianos ou brasileiros com pai ou mãe italiana optaram por se casar com um parceiro na

TABELA 6

Endogamia oculta entre italianos

Município de São Carlos - 1900-1925

\begin{tabular}{|c|c|c|c|c|c|c|}
\hline Casos & 1900 & 1905 & 1910 & 1915 & 1920 & 1925 \\
\hline Noivo brasileiro com sobrenome italiano casado com italiana & 0 & 0 & 8 & 5 & 2 & 6 \\
\hline Noiva brasileira com sobrenome italiano casada com italiano & 2 & 3 & 20 & 35 & 14 & 14 \\
\hline $\begin{array}{l}\text { Noiva brasileira com sobrenome italiano casada com noivo } \\
\text { brasileiro com sobrenome italiano }\end{array}$ & 0 & 0 & 6 & 20 & 62 & 97 \\
\hline Total de casos & 2 & 3 & 34 & 60 & 78 & 117 \\
\hline
\end{tabular}

Fonte: Livros Paroquiais de Registro de Casamentos, 1900, 1905, 1910, 1915, 1920 e 1925.

\section{GRÁFICO 6}

Percentuais de endogamia masculina e feminina (simples e oculta) entre italianos Município de São Carlos - 1900-1925

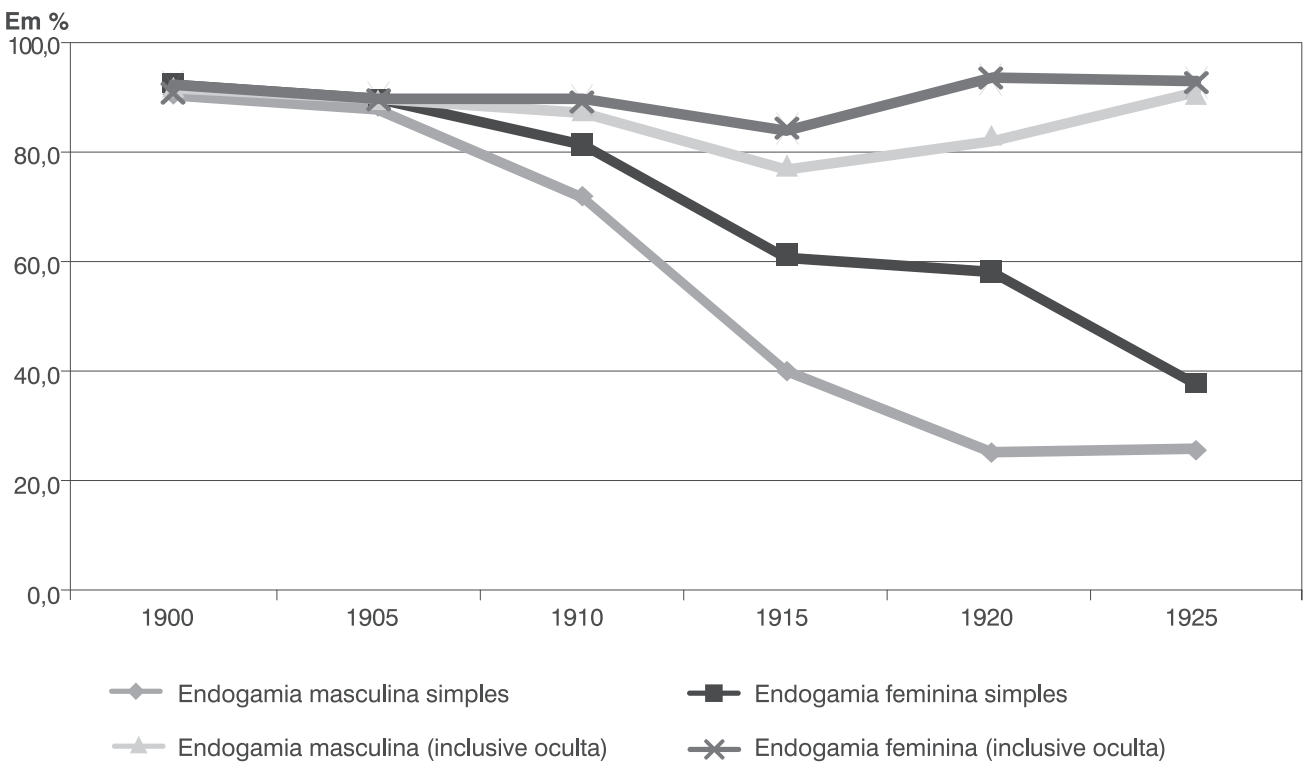

Fonte: Livros Paroquiais de Registro de Casamentos, 1900, 1905, 1910, 1915, 1920 e 1925.

\footnotetext{
17 Antes de 1900, não há (ou são muito raros) filhos(as) de italianos nascidos no Brasil com idade para se casar.
} 


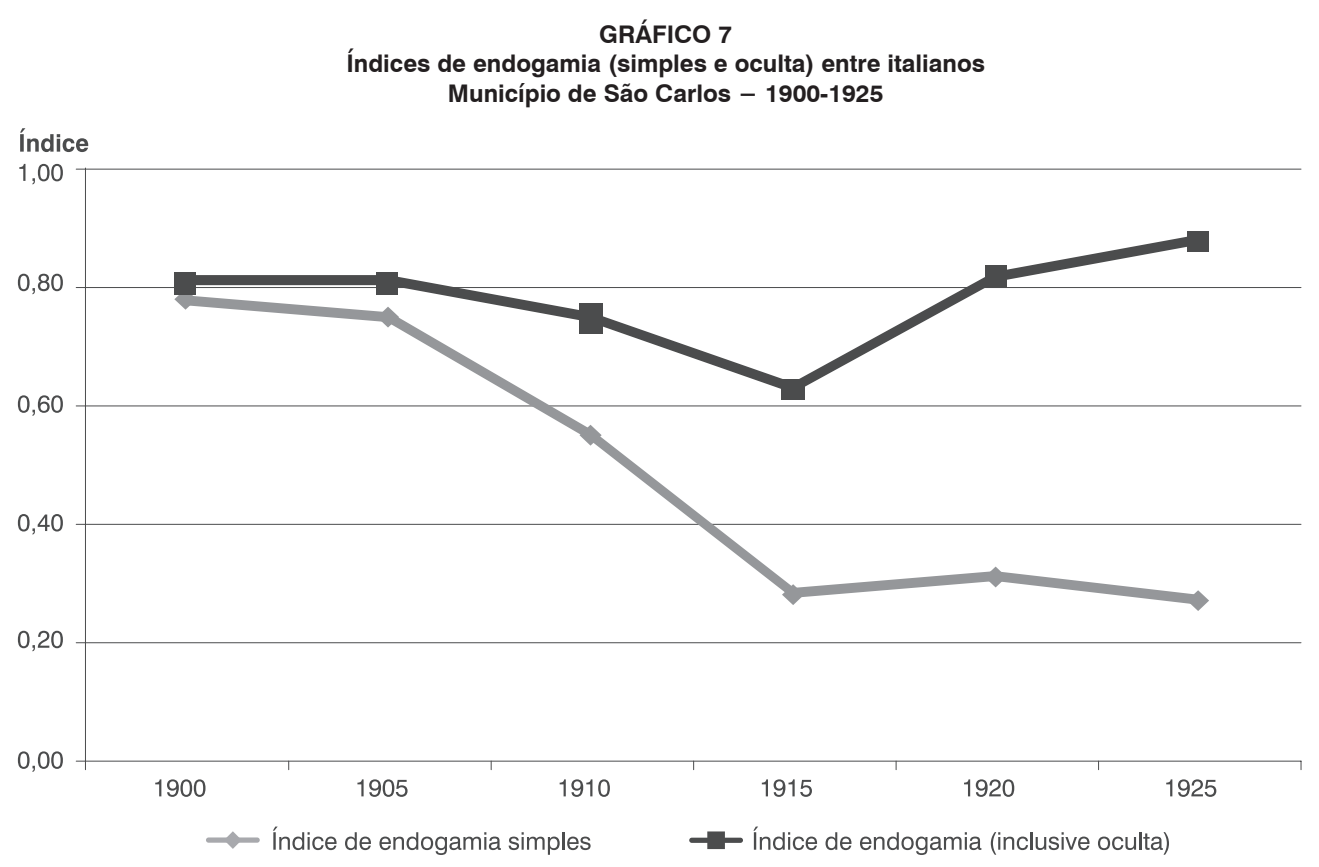

Fonte: Livros Paroquiais de Registro de Casamentos, 1900, 1905, 1910, 1915, 1920 e 1925.

mesma condição, nos anos sob exame. ${ }^{18}$ No Gráfico 7, a correção de cálculo do índice de endogamia - que, recorde-se, varia entre -1 e 1 - igualmente o lança em patamares superiores a 0,60 .

\section{Padrões de exogamia}

Todos os dados até agora processados - utilizando tanto os percentuais quanto os índices de endogamia e ignorando ou considerando o cálculo da endogamia oculta, como fizemos para os italianos - demonstram a influência da origem étnica nacional na escolha do parceiro. Além do já exposto, para se completar a investigação sobre o comportamento matrimonial dos diferentes grupos aqui analisados, falta ainda obter alguma referência sobre os padrões de exogamia vigentes. Em outras palavras, cabe a questão: quando indivíduos de determinado grupo não se casam com seus conterrâneos e casam-se preferencialmente em que outro grupo? Isto é, que grupos distintos, segundo a origem nacional, tendem a se atrair ou a se repelir? O cálculo do índice de endogamia - não apenas para cônjuges da mesma origem (como fizemos anteriormente), mas também para todas as 16 combinações possíveis entre as quatro nacionalidades analisadas - responde a tais questões. Como seria extenuante, além de impróprio, calcular os 16 índices ano a ano, optou-se por calculá-los levando em conta todo o período entre 1893 e 1930 sob análise, conforme ilustra a Tabela 7 . Claro está que, nesta operação, perde-se a noção de como evoluíram tais índices ao longo do tempo, mas o mais importante aqui é se ter uma ideia geral das afinidades na consecução dos casais.

Observe-se que quatro dos cinco valores positivos apurados encontram-se na diagonal da tabela, evidenciando o que já se expôs anteriormente, no Gráfico 5: padrões endogâmicos para cônjuges de mesma

\footnotetext{
18 Apenas em 1915 a endogamia masculina (incluindo-se a oculta) se situa abaixo dos $80 \%$.
} 
TABELA 7

Índices de endogamia (exogamia) entre diferentes possibilidades de casais Município de São Carlos - 1839/1930

\begin{tabular}{lcccc}
\hline \multirow{2}{*}{ Homens } & \multicolumn{3}{c}{ Mulheres } \\
\cline { 2 - 5 } & Brasileiras & Italianas & Portuguesas & Espanholas \\
\hline Brasileiros & 0,67 & $-0,57$ & $-0,16$ & $-0,13$ \\
Italianos & $-0,57$ & 0,72 & $-0,10$ & $-0,07$ \\
Portugueses & $-0,11$ & $-0,12$ & 0,51 & 0,01 \\
Espanhóis & $-0,12$ & $-0,08$ & $-0,02$ & 0,49 \\
\hline
\end{tabular}

Fonte: Livros Paroquiais de Registro de Casamentos, 1883-1930.

nacionalidade (maiores entre brasileiros $\mathrm{e}$ entre italianos - 0,67 e 0,72 - do que entre portugueses e entre espanhóis - 0,51 e 0,49 ). Entre cônjuges de nacionalidades diferentes, os índices obtidos entre portugueses e espanholas $(0,01)$ e, ao contrário, entre espanhóis e portuguesas $(-0,02)$, muito próximos de zero, indicam que, entre ibéricos, a origem nacional lhes é indiferente e as frequências de casamentos encontram-se muito próximas da situação de aleatoriedade. Já os italianos (e italianas) apresentam as maiores restrições para se casar fora do grupo: quando o fazem, preferem nitidamente espanholas/espanhóis $(-0,07 /-0,08)$ ou portuguesas/portugueses $(-0,10 /-0,12)$ do que brasileiras/brasileiros $(-0,57$ para ambos). O mesmo não se observa entre portugueses(as) e espanhóis(olas), cuja "rejeição" ao casamento com brasileiros e brasileiras é muito mais discreta: $-0,11$ e $-0,16$ para os primeiros e $-0,12$ e 0,13 para os últimos. ${ }^{19}$ Por fim, os brasileiros apresentam também um comportamento bastante endogâmico, já que o número de casamentos realizados com estrangeiros apresenta-se muito abaixo do que deveria ao acaso ocorrer.

\section{Conclusões}

Ao se analisar como evoluíram as pautas matrimoniais no município de São Carlos nas sete décadas compreendidas no período 1860-1930, pode-se, em primeiro lugar, observar uma altíssima endogamia quanto à condição de livre ou de escravo dos nubentes no período pré-abolição.

A partir de 1880, o enorme afluxo de imigrantes estrangeiros, sobretudo de origem italiana, alterou profundamente o perfil populacional da região. Quando considerada a nacionalidade dos cônjuges, observam-se igualmente padrões endogâmicos bastante acentuados ao longo de todo o período analisado, maior para mulheres estrangeiras (em relação a homens estrangeiros ou mulheres brasileiras), em razão de sua maior escassez em regiões, na época, receptoras de fluxos migratórios relevantes.

A aparente queda nos indicadores de endogamia a partir de 1909 reflete apenas os casamentos de italianos(as) com brasileiras(os) filhas(os) de italianos(as), o que pouco significa em termos de perda da identidade étnica orientando opções conjugais. Assim, as altas taxas endogâmicas persistem de modo geral até o final do período analisado, sobretudo ao serem considerados os casos de endogamia oculta aludidos. Elas são menores no caso de portugueses, o que sugere que uma razão de sexo muito discrepante associada a um determinado grupo parece impor certa cota de exogamia, também favorecida nesse caso por uma urbanização mais precoce em relação a outros contingentes de estrangeiros. Nesse ponto, embora a inexistência

\footnotetext{
19 Se fosse computada a endogamia oculta, as restrições dos italianos para se casar com brasileiros seriam ainda maiores do que as de portugueses e espanhóis, pelo menos durante certo período, uma vez que, como já observado, o grosso da imigração italiana precedeu a de portugueses e espanhóis, o que significa que os(as) italianos(as) tiveram antes destes a oportunidade de se casar com filhos(as) brasileiros(as) de pais italianos.
} 
de dados sobre o local de moradia nos registros paroquiais impeça uma análise da influência do meio (rural ou urbano) sobre as pautas nupciais, é de se esperar que o meio urbano, ao propiciar maior variedade de interações, favoreça comportamentos exogâmicos (BASSANEZI, 2003, p. 269; CONCEIÇÃO, 2004, p. 84).

Entre italianos em particular, até pelo menos a Primeira Guerra Mundial, os padrões endogâmicos analisados são muito expressivos. Como argumentam Levy e Scarano (1999, p. 64), como a imigração até então era encarada como projeto temporário, "esse propósito vai direcionar os casamentos com parceiras da mesma nacionalidade, a fim de facilitar uma possível volta, o que seria difícil se o casamento fosse com pessoa estranha à mesma origem".

A ausência de dados sobre a cor dos nubentes nos registros paroquiais impede uma análise da endogamia segundo critérios raciais. Mas tudo indica que estas tenham sido expressivas, ainda que uniões inter-raciais existissem e, como esperado, provocassem o horror entre conterrâneos oriundi: "Os noivinhos de cor não desagradam a muitas das nossas Desdêmonas da gleba, e aliás são preferidos até a italianos de outros compartimentos. Essa singular perversão do gosto (me desculpem a expressão os negros, aos quais não quero mal desde que se entendam entre si) é um fenômeno não muito raro no Estado de São Paulo" (DE ZETTIRY, 1893). Nesse mesmo sentido, Oliveira (2008, p.177) destaca que uma das formas para se desclassificar o italiano (em Jaú) era o jornal local publicar notas relativas a matrimônios em que um dos cônjuges era de origem italiana e o outro da raça negra, colocando em destaque tais origens.

De qualquer modo, os dados indicam uma forte identidade étnica no âmbito das relações familiares. Como interpretá-la? Sendo o colonato um regime de trabalho assentado sobre bases familiares, a sobre- vivência ou mobilidade socioeconômica destas unidades repousava fundamentalmente sobre as atitudes dos indivíduos diante do trabalho. E o casamento, de forma coerente, procurava associar capacidades de trabalho percebidas como promissoras, entre cônjuges saudáveis, fisicamente aptos a estabelecer uma prole numerosa e, sobretudo, dispostos a subir na vida pelo trabalho. Para perseguir tal intuito, era mais fácil se casar com gente conhecida, de confiança, de mesma origem e predisposições comuns. Daí as reservas, logo convertidas em estereótipos, em relação aos casamentos com brasileiros, vistos como indolentes e pouco dispostos ao trabalho.

Entre os muitos exemplos ilustrativos dessa situação, podem-se destacar os versos conformados que um pretendente recusado enviou à sua amada: "Teu pai mesmo não quer / Mesmo ele tem muita razão / Se eu fosse um italiano / Eu seria muito bão / Por eu ser brasileiro / Ele não me presta atenção" (FAVARO, 1996, p. 284). Em outras palavras, os imigrantes procuravam - e sofriam pressões da família - praticar condutas matrimoniais que tendiam a potencializar as condições de sobrevivência e mobilidade socioeconômica. Para tal, nada melhor do que eleger, quando disponíveis, parceiros com perspectivas e identidades culturais em comum.

Tais conclusões não se alinham com a ideia de uma fácil assimilação, de um melting pot virtuoso. Os dados expostos nesse trabalho parecem indicar que não houve um rápido processo de homogeneização, como faz crer a bibliografia clássica disponível, no mais das vezes disposta a ressaltar a eficiência da assimilação étnica no Brasil e, em particular, em São Paulo. ${ }^{20}$ Se tomarmos a seleção do cônjuge como parâmetro para aferir a integração social dos imigrantes, ou, pelo polo oposto, para atestar o vigor com que as identidades étnicas se reproduziram na nova terra, uma

20 Entre vários autores, consultar Ellis Jr. (1934, p. 85 e 124); Diegues Jr. (1964, p. 97-99); Trento (1989, p.204); Oliveira (1996, p. 224); Marger (1994, p. 429); Cenni (2002, p. 293-7). 
alta endogamia constitui um indicativo da fraca integração social e de laços étnicos persistentes. Ao contrário, o pressuposto de um cadinho de raças funcionando a todo vapor e pautado por padrões de rápida assimilação deveria vir acompanhado de baixos percentuais e índices endogâmicos, isto é, estes não deveriam superar em muito o nível que a aleatoriedade impõe como normal.

Entretanto, ao menos no município analisado, que pode servir de referência a áreas significativas de recebimento de imigrantes do interior paulista, não foi isso o que ocorreu. Assim, a seleção de cônjuges não apenas expôs uma persistente clivagem entre brasileiros e europeus, como também há evidências de uma forte preferência endogâmica no interior de cada grupo nacional. Todos os dados analisados indicam que, em primeiro lugar, a condição social (de escravo ou livre) e, depois, a origem nacional atuaram como condicionantes muito significativos das opções matrimoniais efetivamente concretizadas até pelo menos o final dos anos 1920.

Tais evidências sugerem a necessidade de se repensar a vigência do modelo de assimilação clássico, diluidor das características étnicas de cada grupo imigrante, no período analisado. A julgar São Carlos como indicativo, os resultados apurados não endossam a crença de que, de modo geral, o Estado de São Paulo permaneceu desde o início da grande imigração infenso a tensões étnicas envolvendo projetos familiares. Ao contrário, os dados colhidos sugerem a existência de amplas distâncias sociais e culturais que tiveram de ser encurtadas ao longo de pelo menos duas gerações antes que imigrantes e brasileiros pudessem efetivamente se misturar e viver juntos. Se isso faz sentido para grupos como italianos, portugueses e espanhóis, em muito maior proporção o faz para outros grupos culturalmente mais distantes, como alemães, sírios e libaneses ou, mais tarde, japoneses.

As evidências indicam que pelo menos as primeiras duas gerações de indivíduos de origem imigrante que viveram no interior de São Paulo até a Grande Depressão do final dos anos 1920 mostraram-se bastante resistentes ao processo de assimilação, pelo menos sob o ângulo das pautas matrimoniais. Se o sistema de recrutamento nas fazendas paulistas embaralhava imigrantes de diferentes origens, dificultando aglomerações étnicas (e inclusive o surgimento de bairros étnicos no meio urbano) e a prepotência dos fazendeiros tampouco permitia a organização em associações no meio rural, o sustentáculo dos vínculos étnicos resistiu no âmbito das relações familiares, em particular nas estratégias de casamento, pautadas por uma forte endogamia.

A partir dos anos 1930 e 1940, é provável que as novas gerações tenham reformado tais condutas, não apenas porque os laços de origem se tornaram no tempo mais distantes, mas também porque a revolução de 1932 em São Paulo (unindo nativos e imigrantes lado a lado), o abrupto declínio da imigração estrangeira, a chegada de novos imigrantes mineiros e nordestinos, a campanha de nacionalização encetada por Vargas durante o Estado Novo, a derrota da Itália no conflito bélico mundial e, por fim, as novas oportunidades de participação no sistema político formal no pós-guerra contribuíram para desarmar o vigor da origem étnica como critério de conduta social. Somente então - e, diga-se de passagem, em contraste com os negros - os imigrantes foram definitivamente incorporados ao tecido social paulista, integrando de forma plena não apenas as classes médias em expansão, mas também as elites interioranas de cada município do Estado impactado pelo fenômeno da imigração em massa no meio século transcorrido entre 1880 e 1930. 


\section{Referências}

AZEVEDO, T. As regras do namoro à antiga. São Paulo: Ática, 1986.

BAILY, S. L. Marriage patterns and immigrant assimilation in Buenos Aires, 1882-1923. Hispanic American Historical Review, v. 60, n.1, p. 32-48, 1980.

BARRON, M. People who intermarry Intermarriage in a New England industrial community. Syracuse: Syracuse University Press, 1946.

BASSANEZI, M. S. Family and immigration in the brazilian past. In: BAILY, S.; MÍGUEZ, E. Mass migration to modern Latin America. Wilmington: Jaguar, 2003, p. 263-77.

. (Org.). São Paulo do passado

- dados demográficos. Campinas: Nepo/ Unicamp, 2000.

Sposarsi nel Brasile: alguns aspectos da nupcialidade entre imigrantes italianos. In: DE BONI, L. (Org.). A presença italiana no Brasil. Vol. III. Porto Alegre e Torino: EST e Fondazione Giovanni Agnelli, 1996, p. $267-80$.

BASSANEZI, M. S.; FRANCISCO, P. Estrangeiros no Estado de São Paulo Estatística demógrafo-sanitária, 1893-1928. Campinas: Nepo/Unicamp, CD-ROM, 2004.

BORGES, M. Chains of gold - Portuguese migration to Argentina in transatlantic perspective. Leiden: Brill, 2009.

BREGER, R.; HILL, R. Cross-cultural marriage - Identity and choice. Oxford and New York: Berg, 1998.

CENNI, F. Italianos no Brasil. São Paulo: Edusp, 2002.

CONCEIÇÃO, S. Imigração e casamentos: o caso de São Carlos (1890 a 1939). Dissertação (Mestrado). São Carlos: CECH/ UFSCar, 2004.

DEVOTO, F. Historia de la inmigración en la Argentina. Buenos Aires: Editorial Sudamericana, 2004.

DE ZETTIRY, A. I coloni italiani nello stato di S. Paolo. La Rassegna Nazionale, v. 70, n. 15, p. 66-70, 1893.
DIEGUES JR., M. Imigração. Urbanização. Industrialização. Rio de Janeiro: Inep, 1964.

ELLIS JR., A. Populações paulistas. São Paulo: Cia. Editora Nacional, 1934.

FAVARO, C. Amor à italiana. In: DE BONI, L. (Org.) A presença italiana no Brasil. Vol. III. Porto Alegre e Torino: EST e Fondazione Giovanni Agnelli, 1996, p. 281-6.

GOEBEL, M. Gaúchos, gringos and gallegos: the assimilation of Italian and Spanish immigrants in the making of modern Uruguay 1880-1930. Past \& Present, n. 208, p. 207-229.

HOLLOWAY, T. Imigrantes para o café. São Paulo: Paz e Terra, 1984.

LEVY, M. S. F. A escolha do cônjuge. Revista Brasileira de Estudos de População, v. 26, n. 1, p. 117-133, jan./jun. 2009.

LEVY, M. S. F.; SCARANO, J. O imigrante em São Paulo: casamento e nupcialidade. Revista População e Família, São Paulo, v. 2, 1999.

MACHADO, A. A. Brás, Bexiga e Barra Funda. São Paulo: Nova Alexandria, 1927.

MARGER, M. Race and ethnic relations. American and global perspectives. 3. ed. Belmont: Wadsworth, 1994.

MIGUEZ, E. J. et al. Hasta que la Argentina nos una: reconsiderando las pautas matrimoniales de los inmigrantes, el crisol de razas y el pluralismo cultural. Hispanic American Historical Review, v. 71, n. 4, p. 781-808, 1991.

MITTELBACH, F.;MOORE, J. Ethnic endogamy - The case of mexican americans. American Journal of Sociology, Chicago, v. 74, n. 1, p. 50-62, 1968.

MOYA, J. Cousins and strangers - Spanish immigrants in Buenos Aires, 1850-1930. Berkeley: University of California Press, 1998.

OLIVEIRA, F. A. M. Italianos na cidade de Jaú por volta do início do século XX. In: DE BONI, L. (Org.). A presença italiana no Brasil. 
Vol. III. Porto Alegre e Torino: EST e Fondazione Giovanni Agnelli, 1996, p. 213-24.

. Italianos no Novo Mundo: imigrantes italianos na conquista de um espaço social na cidade de Jaú (1870-1914). São Paulo: Editora Unesp, 2008.

OTERO, H. Uma visión critica de la endogamia: reflexiones a partir de uma reconstrucción de famílias francesas (Tandil, 1850-1914). Estudios Migratorios Latinoamericanos, n. 15-16, p. 343-377, 1990.

PAGANO, N.;OPORTO, M. La conducta endogámica de los grupos inmigrantes: pautas matrimoniales de los italianos em el barrio de La Boca em 1895. In: DEVOTO, F.; ROSOLI, G. (a cura di). L' Italia nella società argentina. Roma: Centro Studi Emigrazione, 1988, p. 90-101.

SAVORGNAN, F. Matrimonial selection and amalgamation of heterogeneous groups. In: INTERNATIONAL UNION FOR THE SCIENTIFIC STUDY OF POPULATION
(IUSSP). Cultural assimilation of immigrants. London, 1950, p. 59-67.

SOLLORS, W. (Ed.). Interracialism - Blackwhite intermarriage in American history, literature and law. Oxford: Oxford University Press, 2000.

SZUCHMAN, M. The limits of the melting pot in urban Argentina: marriage and integration in Córdoba, 1869-1909. Hispanic American Historical Review, v. 57, n. 1, p. 24-50, 1997.

TRENTO, A. Do outro lado do Atlântico um século de imigração italiana no Brasil. São Paulo: Nobel, 1989.

TRUZZI, O. Café e indústria: São Carlos, 1850-1950. 3. ed. São Paulo e São Carlos: Imprensa Oficial do Estado e EdUFSCar, 2007.

TRUZZI, O.; BASSANEZI, M. S. População, grupos étnico-raciais e economia cafeeira: São Carlos, 1907. Revista Brasileira de Estudos de População. v. 26, n. 2, p. 197218, 2009.

\section{Resumem}

Patrones de nupcialidad en la economía cafetera de Sao Paulo (1860-1930)

El objetivo de este trabajo es presentar y discutir las pautas matrimoniales vigentes en un municipio típico de la economía cafetera paulista, entre 1860 y 1930, tomando tal variable como un indicador del vigor de la identidad étnica y del grado de asimilación de los extranjeros en la sociedad local. San Carlos fue fundado en 1857 y se convirtió, a partir de la penúltima década del siglo XIX, en un municipio bastante representativo de la economía cafetera que se desarrolló en el estado de Sao Paulo. De hecho, con una mano de obra inicialmente compuesta por esclavos negros, a partir del año 1880 y en adelante, el municipio pasó a recibir ingentes masas de inmigrantes europeos - italianos, portugueses, españoles y otros numéricamente menos significativos- para trabajar en las plantaciones de café, hasta el punto de que, en 1894, había recibido el mayor contingente de inmigrantes de todo el interior del estado de Sao Paulo. A partir de un análisis de los 15.011 registros parroquiales de matrimonio observados en el período, el trabajo discute la evolución de las preferencias matrimoniales de esos diversos grupos que, junto a los brasileños blancos y negros, conformaron una población estimada en 60 mil individuos en 1930. Los datos analizados indican que el origen nacional actuó como un condicionante muy significativo en las opciones matrimoniales, efectivamente consumadas en matrimonios, hasta por lo menos final de los años veinte del siglo pasado. Así pues, las evidencias recogidas apuntan a que por lo menos las primeras dos generaciones de individuos de origen inmigrante, que vivieron en San Carlos hasta la Gran Depresión del final de la década de 1920, se mostraron bastante resistentes al proceso de asimilación, por lo menos bajo el ángulo de las pautas matrimoniales.

Palabras-clave: Matrimonios. Inmigración. Endogamia. Etnicidad. Economía cafetera. Sao Paulo. 


\begin{abstract}
Marriage patterns in São Paulo coffee economy (1860-1930)

This paper discusses marriage patterns in a representative city in the state of São Paulo during the coffee economy of 1860-1930. It takes these patterns as indicators of the strength of ethnic identities and of the assimilation of European immigrants in the local society. The city of São Carlos was founded in 1857 and by the late $19^{\text {th }}$ century, it can be seen as fairly typical of the coffee economy that developed in the state of São Paulo. In fact, with a workforce initially composed of African slaves, from the 1880s the city began to receive significant waves of European immigrants - Italians, Portuguese, Spanish and other less numerically significant - for work on coffee plantations, to the point that, in the year of 1894 , it received the highest number of immigrants in all of the state, except for the capital. From an analysis of 15,011 parish registers of marriage observed in the period, this paper discusses the evolution of marriage preferences among diverse groups that, alongside black and white Brazilians, conformed an estimated population of 60,000 individuals in 1930 . The data analyzed indicate that national origin served as very significant determinant of marital options effectively implemented until at least the late 1920s. Thus, the evidence gathered indicates that at least the first two generations of persons of immigrant origins, living in São Carlos until the Great Depression in the late 1920s, were quite resistant to the process of assimilation, at least in regards to marriage patterns.
\end{abstract}

Keywords: Marriage. Immigation. Inbreeding. Ethnicity. Coffee economy. São Paulo.

Recebido para publicação em 17/08/2012

Aceito para publicação em 01/01/2012

\title{
ANEXO
}

\section{Cálculo do Índice de Endogamia}

O índice de endogamia para determinada característica (neste caso, origem) é calculado pela seguinte fórmula:

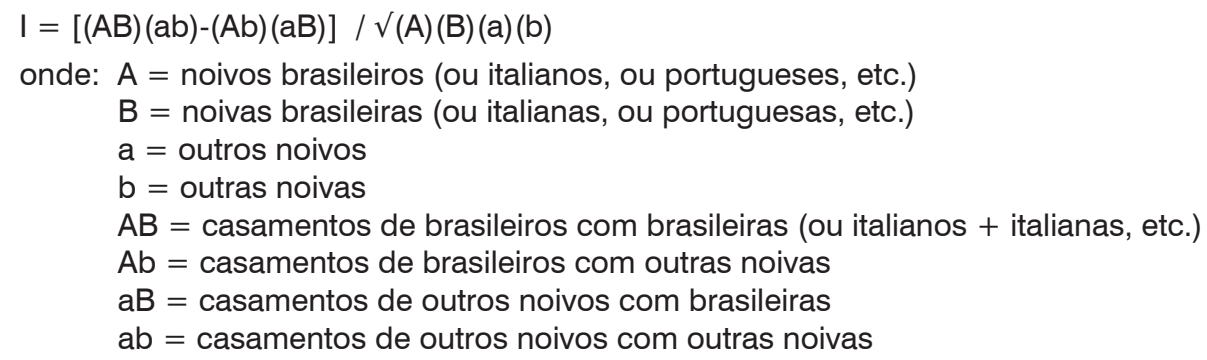

(fonte: Savorgnan, 1950). 
TABELA 1

Percentuais de endogamia masculina, por nacionalidade Município de São Carlos 1883-1930

\begin{tabular}{rrrrr|rrrrr|lllll}
\hline Anos & Itals. & Ports. Esps. & Bras. & Anos & Itals. & Ports. & Esps. & Bras. & Anos & Itals. & Ports. & Esps. & Bras. \\
\hline 1883 & 16,7 & 80,0 & 0,0 & 96,4 & 1899 & 93,2 & 87,5 & 42,9 & 93,5 & 1915 & 40,0 & 50,0 & 50,0 & 78,3 \\
1884 & 50,0 & 37,5 & 0,0 & 98,4 & 1900 & 90,5 & 51,9 & 75,0 & 87,5 & 1916 & 35,6 & 27,6 & 73,9 & 81,4 \\
1885 & 33,3 & 40,0 & 0,0 & 98,4 & 1901 & 94,4 & 80,0 & 50,0 & 94,5 & 1917 & 34,1 & 28,6 & 62,5 & 84,3 \\
1886 & 61,5 & 57,1 & 0,0 & 97,2 & 1902 & 94,7 & 55,6 & 75,0 & 85,7 & 1918 & 26,2 & 35,3 & 42,9 & 85,4 \\
1887 & 75,0 & 77,8 & 0,0 & 100,0 & 1903 & 95,9 & 47,8 & 71,4 & 87,0 & 1919 & 24,5 & 23,5 & 47,1 & 87,8 \\
1888 & 91,3 & 53,8 & 0,0 & 98,8 & 1904 & 87,6 & 54,5 & 55,6 & 89,7 & 1920 & 25,0 & 7,1 & 52,2 & 94,4 \\
1889 & 83,3 & 50,0 & 50,0 & 95,8 & 1905 & 87,9 & 43,5 & 87,5 & 90,3 & 1921 & 25,5 & 22,2 & 37,5 & 91,5 \\
1890 & 85,7 & 50,0 & 0,0 & 97,0 & 1906 & 86,2 & 35,0 & 66,7 & 80,3 & 1922 & 24,4 & 27,3 & 41,2 & 93,1 \\
1891 & 92,6 & 64,7 & 40,0 & 95,4 & 1907 & 92,3 & 28,6 & 66,7 & 90,0 & 1923 & 24,2 & 11,1 & 15,4 & 93,2 \\
1892 & 93,0 & 55,2 & 40,0 & 95,4 & 1908 & 93,3 & 36,4 & 80,0 & 94,1 & 1924 & 42,1 & 12,5 & 50,0 & 93,6 \\
1893 & 97,3 & 58,8 & 71,4 & 93,1 & 1909 & 84,0 & 21,4 & 80,0 & 90,3 & 1925 & 25,7 & 20,0 & 45,5 & 91,1 \\
1894 & 94,4 & 57,9 & 46,2 & 97,6 & 1910 & 71,9 & 40,9 & 42,9 & 82,4 & 1926 & 21,7 & 0,0 & 26,3 & 91,8 \\
1895 & 91,7 & 90,9 & 83,3 & 90,8 & 1911 & 62,4 & 34,6 & 50,0 & 82,0 & 1927 & 23,3 & 12,5 & 20,0 & 87,8 \\
1896 & 94,5 & 64,7 & 71,4 & 89,7 & 1912 & 64,5 & 20,0 & 53,8 & 84,5 & 1928 & 7,1 & 35,3 & 25,0 & 92,8 \\
1897 & 94,2 & 40,0 & 33,3 & 90,9 & 1913 & 55,6 & 43,5 & 72,7 & 83,2 & 1929 & 22,2 & 16,7 & 33,3 & 95,7 \\
1898 & 95,7 & 40,9 & 46,2 & 90,4 & 1914 & 45,4 & 42,9 & 58,8 & 79,2 & 1930 & 20,0 & 42,9 & 8,3 & 91,9 \\
\hline
\end{tabular}

Fonte: Livros Paroquiais de Registro de Casamentos, 1883-1930.

TABELA 2

Percentuais de endogamia feminina, por nacionalidade Município de São Carlos - 1883-1930

\begin{tabular}{rrrrr|rrrrr|lllll}
\hline Anos & Itals. & Ports. & Esps. & Bras. & Anos & Itals. & Ports. & Esps. & Bras. & Anos & Itals. & Ports. & Esps. & Bras. \\
\hline 1883 & 100,0 & 80,0 & 0,0 & 90,0 & 1899 & 94,4 & 95,5 & 50,0 & 82,9 & 1915 & 61,0 & 61,1 & 62,5 & 58,4 \\
1884 & 75,0 & 60,0 & 0,0 & 83,8 & 1900 & 92,5 & 93,3 & 46,2 & 77,8 & 1916 & 56,4 & 72,7 & 60,7 & 61,5 \\
1885 & 100,0 & 44,4 & 0,0 & 82,7 & 1901 & 94,4 & 83,3 & 75,0 & 88,5 & 1917 & 58,8 & 60,0 & 66,7 & 64,5 \\
1886 & 88,9 & 80,0 & 0,0 & 89,7 & 1902 & 94,7 & 58,8 & 60,0 & 86,7 & 1918 & 53,1 & 85,7 & 35,3 & 65,4 \\
1887 & 100,0 & 100,0 & 0,0 & 84,1 & 1903 & 95,9 & 78,6 & 55,6 & 75,8 & 1919 & 40,6 & 57,1 & 47,1 & 77,4 \\
1888 & 95,5 & 77,8 & 0,0 & 97,1 & 1904 & 88,3 & 75,0 & 55,6 & 81,4 & 1920 & 57,9 & 16,7 & 80,0 & 79,1 \\
1889 & 84,7 & 50,0 & 100,0 & 94,6 & 1905 & 89,9 & 83,3 & 53,8 & 82,3 & 1921 & 50,0 & 66,7 & 50,0 & 77,5 \\
1890 & 94,1 & 60,0 & 0,0 & 89,5 & 1906 & 91,1 & 53,8 & 28,6 & 72,6 & 1922 & 52,6 & 33,3 & 46,7 & 83,9 \\
1891 & 95,5 & 73,3 & 100,0 & 90,4 & 1907 & 95,0 & 57,1 & 50,0 & 77,1 & 1923 & 42,1 & 40,0 & 20,0 & 84,4 \\
1892 & 95,5 & 88,9 & 33,3 & 90,1 & 1908 & 96,6 & 100,0 & 57,1 & 69,6 & 1924 & 64,0 & 50,0 & 47,6 & 85,4 \\
1893 & 97,3 & 66,7 & 62,5 & 93,1 & 1909 & 90,1 & 66,7 & 70,6 & 63,6 & 1925 & 37,5 & 27,3 & 52,6 & 87,7 \\
1894 & 92,9 & 68,8 & 85,7 & 89,2 & 1910 & 81,3 & 64,3 & 33,3 & 66,1 & 1926 & 31,3 & 0,0 & 27,8 & 87,2 \\
1895 & 93,5 & 87,0 & 62,5 & 89,2 & 1911 & 75,9 & 90,0 & 53,8 & 60,3 & 1927 & 36,8 & 25,0 & 28,6 & 87,1 \\
1896 & 91,0 & 84,6 & 83,3 & 90,7 & 1912 & 78,0 & 44,4 & 58,3 & 66,5 & 1928 & 28,6 & 42,9 & 46,2 & 85,1 \\
1897 & 92,9 & 60,0 & 20,0 & 87,5 & 1913 & 74,1 & 62,5 & 76,2 & 66,7 & 1929 & 30,8 & 66,7 & 36,4 & 91,5 \\
1898 & 90,6 & 90,0 & 75,0 & 80,5 & 1914 & 78,6 & 50,0 & 55,6 & 55,1 & 1930 & 30,0 & 50,0 & 16,7 & 58,8 \\
\hline
\end{tabular}

Fonte: Livros Paroquiais de Registro de Casamentos, 1883-1930. 
TABELA 3

Índice de endogamia, por nacionalidade

Município de São Carlos - 1883-1930

\begin{tabular}{ccccc|ccccc|ccccc}
\hline Anos & Itals. & Ports. & Esps. & Bras. & Ano & Itals. & Ports. & Esps. & Bras. & Ano & Itals. & Ports. & Esps. & Bras. \\
\hline 1883 & 0,39 & 0,79 & 0,00 & 0,84 & 1899 & 0,81 & 0,90 & 0,45 & 0,84 & 1915 & 0,28 & 0,52 & 0,53 & 0,30 \\
1884 & 0,45 & 0,44 & 0,00 & 0,75 & 1900 & 0,78 & 0,67 & 0,57 & 0,76 & 1916 & 0,23 & 0,41 & 0,64 & 0,31 \\
1885 & 0,43 & 0,37 & 0,00 & 0,75 & 1901 & 0,84 & 0,84 & 0,60 & 0,88 & 1917 & 0,29 & 0,39 & 0,33 & 0,27 \\
1886 & 0,71 & 0,66 & 0,00 & 0,80 & 1902 & 0,86 & 0,86 & 0,67 & 0,80 & 1918 & 0,23 & 0,53 & 0,35 & 0,26 \\
1887 & 0,86 & 0,87 & 0,00 & 0,80 & 1903 & 0,88 & 0,58 & 0,62 & 0,74 & 1919 & 0,23 & 0,35 & 0,44 & 0,28 \\
1888 & 0,93 & 0,64 & 0,00 & 0,88 & 1904 & 0,74 & 0,61 & 0,54 & 0,78 & 1920 & 0,31 & 0,08 & 0,62 & 0,40 \\
1889 & 0,78 & 0,48 & 0,71 & 0,80 & 1905 & 0,75 & 0,58 & 0,67 & 0,77 & 1921 & 0,28 & 0,37 & 0,40 & 0,26 \\
1890 & 0,86 & 0,54 & 0,00 & 0,79 & 1906 & 0,73 & 0,73 & 0,43 & 0,66 & 1922 & 0,31 & 0,28 & 0,41 & 0,34 \\
1891 & 0,92 & 0,66 & 0,63 & 0,84 & 1907 & 0,83 & 0,38 & 0,56 & 0,76 & 1923 & 0,23 & 0,19 & 0,15 & 0,32 \\
1892 & 0,88 & 0,68 & 0,35 & 0,85 & 1908 & 0,86 & 0,39 & 0,66 & 0,76 & 1924 & 0,45 & 0,23 & 0,46 & 0,43 \\
1893 & 0,95 & 0,60 & 0,66 & 0,88 & 1909 & 0,75 & 0,34 & 0,73 & 0,65 & 1925 & 0,27 & 0,21 & 0,46 & 0,36 \\
1894 & 0,89 & 0,60 & 0,81 & 0,90 & 1910 & 0,55 & 0,48 & 0,36 & 0,56 & 1926 & 0,24 & 0,00 & 0,23 & 0,24 \\
1895 & 0,85 & 0,88 & 0,72 & 0,84 & 1911 & 0,50 & 0,53 & 0,49 & 0,44 & 1927 & 0,18 & 0,15 & 0,21 & $-0,13$ \\
1896 & 0,86 & 0,72 & 0,77 & 0,85 & 1912 & 0,52 & 0,26 & 0,54 & 0,50 & 1928 & 0,13 & 0,37 & 0,31 & 0,25 \\
1897 & 0,85 & 0,46 & 0,25 & 0,84 & 1913 & 0,44 & 0,50 & 0,73 & 0,47 & 1929 & 0,23 & 0,32 & 0,33 & 0,47 \\
1898 & 0,91 & 0,59 & 0,57 & 0,79 & 1914 & 0,42 & 0,41 & 0,54 & 0,34 & 1930 & 0,22 & 0,45 & 0,09 & 0,28 \\
\hline
\end{tabular}

Fonte: Livros Paroquiais de Registro de Casamentos, 1883-1930.

TABELA 4

Percentuais de endogamia masculina e feminina (simples e oculta) entre italianos Município de São Carlos - 1900-1925

\begin{tabular}{ccccc}
\hline Anos & $\begin{array}{c}\text { Endogamia } \\
\text { masculina simples }\end{array}$ & $\begin{array}{c}\text { Endogamia } \\
\text { feminina simples }\end{array}$ & $\begin{array}{c}\text { Endogamia masculina } \\
\text { (inclusive oculta) }\end{array}$ & $\begin{array}{c}\text { Endogamia feminina } \\
\text { (inclusive oculta) }\end{array}$ \\
\hline 1900 & 90,5 & 92,5 & 92,0 & 92,6 \\
1905 & 87,9 & 89,9 & 90,1 & 90,1 \\
1910 & 71,9 & 81,3 & 87,6 & 89,9 \\
1915 & 40,0 & 61,0 & 76,8 & 84,2 \\
1920 & 25,0 & 57,9 & 82,4 & 93,7 \\
1925 & 25,7 & 37,5 & 91,3 & 93,3 \\
\hline
\end{tabular}

Fonte: Livros Paroquiais de Registro de Casamentos, 1900, 1905, 1910, 1915, 1920 e 1925.

TABELA 5

Índice de endogamia (simples e oculta) entre italianos

Município de São Carlos - 1900-1925

\begin{tabular}{lcc}
\hline Anos & Índice de endogamia simples & índice de endogamia (inclusive oculta) \\
\hline 1900 & 0,78 & 0,81 \\
1905 & 0,75 & 0,81 \\
1910 & 0,55 & 0,75 \\
1915 & 0,28 & 0,63 \\
1920 & 0,31 & 0,82 \\
1925 & 0,27 & 0,88 \\
\hline
\end{tabular}

Fonte: Livros Paroquiais de Registro de Casamentos, 1900, 1905, 1910, 1915, 1920 e 1925. 